\title{
Threatened flora and forests in the Azores
}

\author{
J. P. Haggar, A. R. Westgarth-Smith and D. Penman
}

The authors visited the Azores in September 1986 to investigate the status of the archipelago's natural forests and the rare endemic trees they contain. They carried out intensive investigation only on the island of Pico, although they also worked on Terceira and Sao Miguel. These three are the only islands on which moderately large areas of forest are believed to remain.

The Azores archipelago, which consists of nine main islands, lies in the Atlantic Ocean $1480 \mathrm{~km}$ west of Portugal (Figure 1). The islands are volcanic with the highest point, O'Pico, at $2351 \mathrm{~m}$. Evergreen forests once covered the islands, but clearance since the Portuguese colonists arrived in the mid-fifteenth century has largely removed this vegetation (Godman, 1870). The antiquity and isolation of the flora is reflected in 8 of the 11 native trees being endemic to the Azores, and

A view of the uplands of Pico, showing fragmented forest on the large mountain in the background, $O$ 'Pico, and on the volcanic cones in the foreground. Between these is the dark area of the completely forested Bosque da Junqueira (J.P. Haggar). 


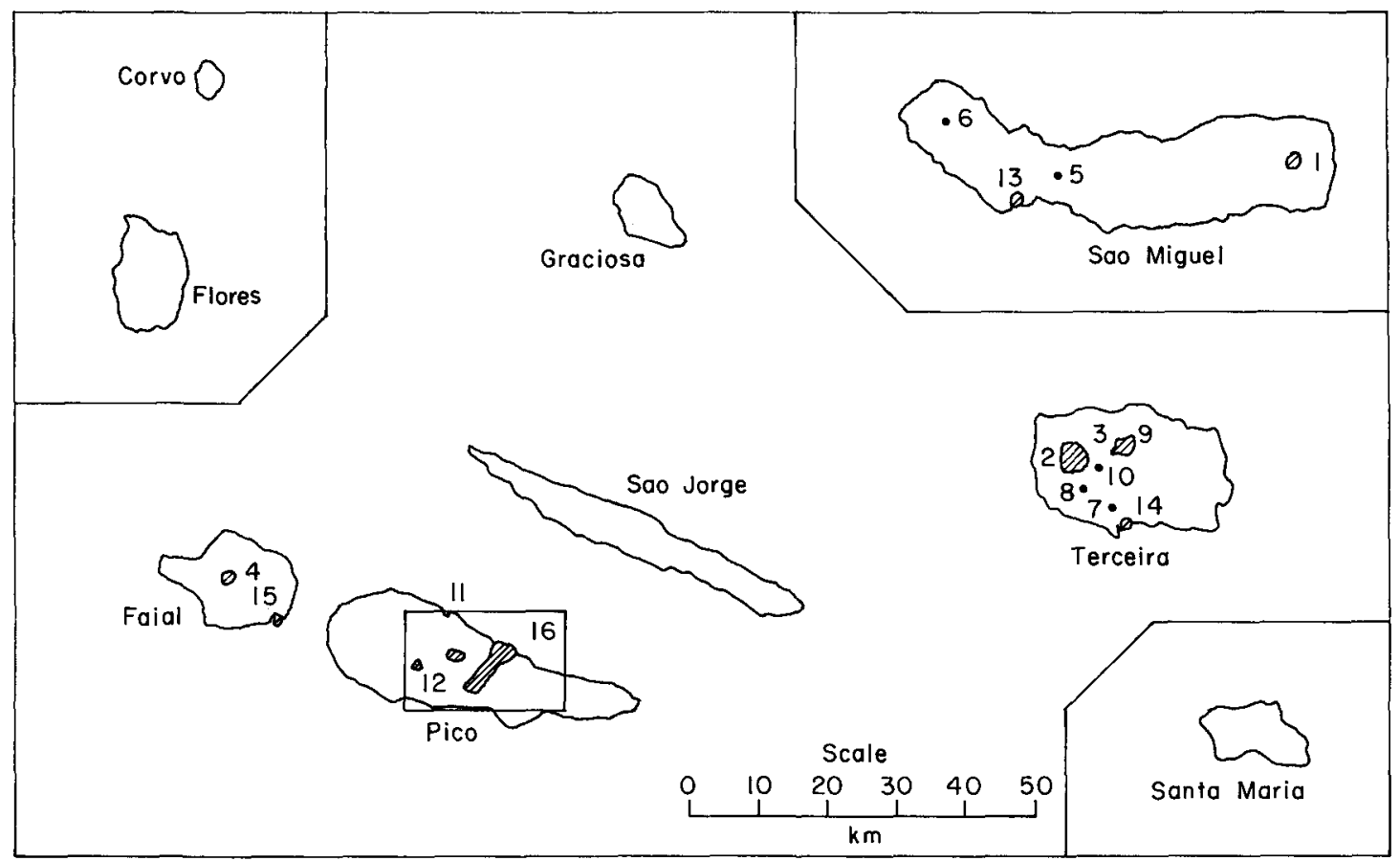

Figure 1. Map of sites in the Azores mentioned in text. Extant forest: (1) Pico da Vara; (2) Caldeira da Santa Barbara; (3) Juncal; (4) Caldeira da Faial. For areas of forest on Pico see Figure 2. Sites of endemic plants: (5) Pico d'Agua; (6) Lagoa do Canario; (7) Terra Cha; (8) Erica Forest site; (9) Pico Alto; (10) Pico da Gaspar; (11) Sao Roque; (12) O'Pico. Towns: (13) Ponta Delgada; (14) Angra do Heroismo; (15) Horta. (16) Area of Pico enlarged in Figure 2.

two others are only otherwise found on Madeira. Although the total vascular flora for the islands is about 850 species, the majority of these have almost certainly been introduced by man, with only 60 taxa being endemic to the islands.

No large areas of natural broad-leaved evergreen forest remain in the lowlands (below $500 \mathrm{~m})$. Apart from widespread clearance for agriculture, the remaining areas of forest have either been planted with introduced species, such as Eucalyptus spp., Acacia spp., Cryptomeria japonica or Pittosporum undulatum, or have been invaded by the latter species. Above $500 \mathrm{~m}$ areas of natural and semi-natural forest do remain. These are cloud forests, which vary in height from $10 \mathrm{~m}$ to only $1 \mathrm{~m}$ in the elfinwood above $1100 \mathrm{~m}$ on Pico. The dominant species include Erica azorica, ${ }^{*}$ Ilex perado ssp. azorica, Juniperus brevifolia and Laurus azorica. The

${ }^{*}$ Nomenclature follows Sjögren (1984). 156 branches and trunks of the trees are covered with epiphytic bryophytes and ferns, while the herbaceous vegetation is dominated by large ferns and the ground is carpeted with moss (Haggar, 1988).

\section{Status of the lowland flora}

The native lowland trees still persist locally in areas such as Terra Cha on Terceira and near Pico d'Agua on Sao Miguel, where species such as Laurus azorica and Picconia azorica form a subcanopy in the plantations of Eucalyptus or Acacia. Also found in these plantations is Persea indica, a Macaronesian endemic that has been introduced to the Azores from Madeira. This species is now rare in Madeira and is probably much more common in the Azores (E. Dias, pers. comm.). However, in the Pittosporum and Cryptomeria plantations, none of the native trees can survive. The other major lowland tree is Myrica faya, which is a shade-intolerant species found only locally on the edges of plantations and in

Oryx Vol 23 No 3, July 1989 
disturbed areas. This species once formed extensive woodlands, but these have largely been taken over by Pittosporum, which prevents the regeneration of $M$. faya. The only area of intact lowland forest is in the south-west of Terceira, where a small area of Erica azorica forest exists on very poor soils. It is also one of the few lowland sites for Juniperus brevifolia.

The only other places in the lowlands where the native trees were observed to be dominant were in the few remaining areas of coastal scrub, such as that just east of Cais do Pico on Pico, where Myrica, Picconia and Erica appear more tolerant of exposure than Pittosporum (Figure 2.)

Picconia azorica has been considered to be one of the rarest trees in the Azores (Sjögren, 1984).
However, although very local in its distribution, we found that it was regenerating well in quite deep shade and may well once have been codominant with Laurus and Myrica in the lowland forest. In the past the tree was much in demand for its hard timber, and in one wood near Sao Roque on Pico the species is grown as standard trees over Pittosporum coppice.

The coastal flora is rich, with several endemic species. It has been greatly affected by coastal development and the dumping of rubbish, but examples are still found in some areas, for example on the lava flows around Cais do Pico, where characteristic species, such as Euphorbia azorica and Juncus acutus, can be found. One of the most vulnerable species is Azorina vidalii, an endemic with a very local natural distribution,

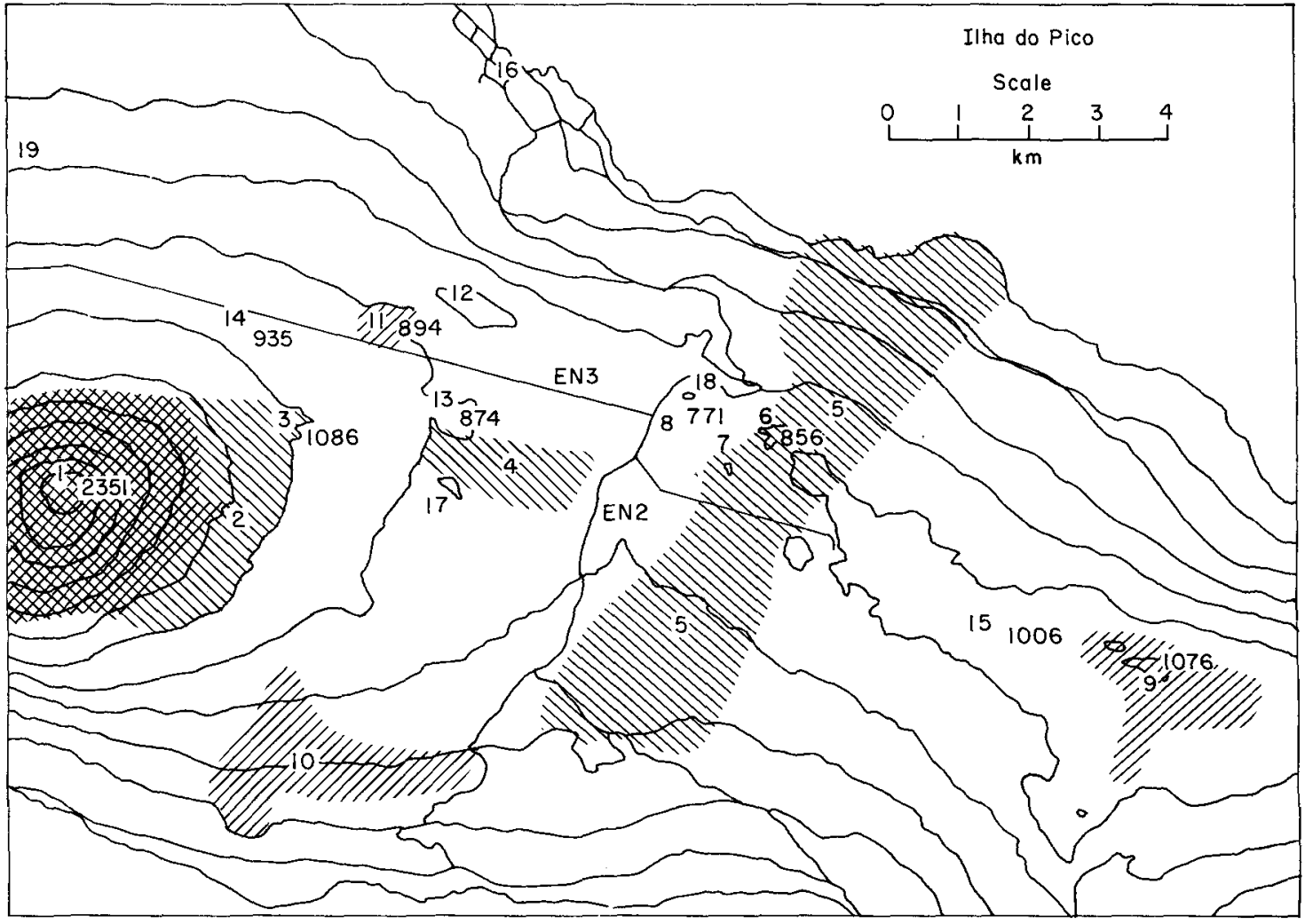

Figure 2. Sites in the Central Section of the Island of Pico, Azores. Protected areas in 1986: (1) O'Pico. Areas requiring protection: (2) Eastern slopes of O'Pico; (3) Cabeço do Escalvado; (4) Bosque da Junqueira; (5) Misterio da Prainha; (6) Chao Verde; (7) Cabeço da Lavandeira; (8) Camp Wood. Areas of forest recently lost: (9) Caveiro; (10) Misterio de Sao Joao; (11) Cabeço do Teixa. Other sites: (12) Lomba; (13) Cabeço do Sintrao; (14) Site of Lactuca watsoniana; (15) Grotöes; (16) Cais do Pico; (17) Cosme; (18) Corre Agua; (19) Misterio da Santa Luzia. Contours are every $200 \mathrm{~m}$. Height in metres. 
such as beneath seabird colonies on Sao Miguel or within the harbour of Cais do Pico. However, on Flores and Corvo it is reported to be much more widespread (G.Le Grand, pers. comm.).

\section{Status of the upland forests}

On Sao Miguel the only remaining area of natural forest is on Pico da Vara. We were unable to visit this area, but it has been studied by Le Grand, Sjögren and Furtado (1982). This is the last remaining area of Laurisilva (vegetation dominated by mesophyll or large broad-leaved trees) in the Azores outside of protected gullies. An area of only 600 ha remains, due to widespread planting of Cryptomeria, which has now stopped because it is uneconomic. This area is the last home of the endemic bullfinch, the priolo Pyrrhula pyrrhula murina.

Terceira has the largest remaining areas of undisturbed forest. These are 5-6 sq $\mathrm{km}$ on the Caldeira da Santa Barbara and 4-5 sq km between Juncal, Pico Alto and Serra do Labaçal. The Caldeira da Santa Barbara, being mostly over $800 \mathrm{~m}$, is often covered with cloud and the forests are largely dominated by low-growing juniper, although some of the lower slopes and gullies, particularly on the north-east side, contain the full array of Azorean tree species. Within the Caldeira there are areas of natural grassland, which are largely composed of endemic grasses and herbs such as Holcus rigidus, Festuca jubata and Tolpis azorica. The Juncal area is lower in altitude, between 500 and $800 \mathrm{~m}$. However, this forest has been virtually unexplored; it is considered to be an area of true virgin forest and probably contains a large array of Azorian forest endemics. The area is surrounded by pasture and Cryptomeria plantations, but these have been abandoned, the latter because of storm damage.

As recently as 1980 , Pico was the most wooded of the islands (Le Grand, 1980) (Figure 1), although much of this cover may be secondary vegetation; Guppy (1917) describes a landscape very similar to the more deforested landscape of 1986, although the few forested areas were better developed in 1917. Very little forest remains on O'Pico; in the previously most wooded area on the eastern slopes (Le Grand, pers. comm.) only fragments, of less than one hectare, of scrub forest were found in gullies. Burnt tree stumps 158 are evidence that the forest had recently been more widespread. At this high altitude, between 1100 and $1400 \mathrm{~m}$, the elfinwood of Juniperus, Erica and Daphne laureola is unique to this island.

The most extensive areas of natural vegetation exist on the Misterio da Prainha, which is a lava flow from an eruption in 1718 and covers about $15 \mathrm{sq} \mathrm{km}$. The vegetation is very immature, being only $0.5-1 \mathrm{~m}$ tall, although it includes most of the endemic Azorean trees and many other plants. Better developed forest can be found on the volcanic cones and older lava flows of the rest of the island, but much has been largely cleared for pasture in the past few years, and clearance continues. The forest of the volcanic cones is the most fragmented. Small areas of juniper high forest remain on Chao Verde and Cabeço da Lavandeira, but they are disturbed by cattle and felling. The rarest vegetation type, however, is undisturbed microphyll broad-leaved forest with a wide range of trees present, including Euphorbia stygiana, and a dense varied understorey of ferns and climbers. Only one such site was found, and that was only a few hectares in extent, on a hill to the south of Corre Agua (Figure 2).

The only remaining large area of moderately well-developed forest is the Bosque da Junqueira, a mixed forest of juniper and broadleaved trees, especially Laurus sp. The best developed areas are to the south-east and to the west, between Cosme and Cabeço do Sintrao, the rest being low-growing scrub. However, it is in the rain shadow of the hills to the north and lacks some of the true cloud-forest species such as Euphorbia stygiana and Culcita macrocarpa. Areas of the cloud forest on lava exist only as degraded scrub forest, with cattle browsing largely eliminating Laurus, Frangula azorica and Hedera helix ssp. canariensis, although Euphorbia and Culcita are persistent. Even this, however, is now being cleared for open pasture, with remnants left on Cabeço do Escalvado and to the east of the road junction of the EN3 and EN2.

Laurisilva on Pico is now restricted to ravines, which in wetter areas harbour local endemics such as the orchid Platanthera micrantha and Sanicula azorica. These rare sites include the gullies on the east side of Cabeço do Sintrao and at the base of Cabeço da Lavandeira.

Oryx Vol 23 No 3, July 1989 


\section{Status of the rare upland endemics}

A specific study was made of Euphorbia stygiana. On Terceira this species is known from four sites: Caldeira da Santa Barbara; Juncal; Pico da Gaspar; and a hill to the south-east of Pico Alto. All these populations are on cliffs, and the species appears to be unable to grow in the mature forest of Terceira (E. Dias, pers. comm.). On Sao Miguel a population of $10-20$ plants is known from Pico da Vara (G. Le Grand, pers. comm.) and on Faial an ageing population occurs in the Caldeira (E. Dias, pers. comm.).

E. stygiana is most abundant on Pico. It appears to be restricted to the areas with the heaviest cloud cover above $700-750 \mathrm{~m}$. It is found up to about $1250 \mathrm{~m}$ on the eastern slopes of O'Pico, and on the northern slopes it is restricted to the craters of parasitic cones. It has also been recorded from the west side of O'Pico (Sjögren, 1973). To the east it is found on the Misterio da Prainha and was recorded by Sjögren (1973) as being present at Grotöes, although this appears to have been largely cleared of forest since then.

The size structure was assessed for three populations across the range of the species on Pico. The results indicated continuing recruitment into the population, but since the range on Pico covers an area of only $15 \mathrm{~km}$ by $3 \mathrm{~km}$, the total population probably does not exceed 500 individuals. Despite the small population it is probably not endangered because it is resistant to cattle browsing and grows on Misterio da Prainha, which is unlikely to be developed.

The most endangered tree in the Azores is Prunus lusitanica ssp. azorica. It used to be found on Pico, but the last known individual on Chao Verde was lost a few years ago (G. Le Grand, pers. comm.). Until recently the only known pcpulation of this tree was on Pico da Vara on Sao Miguel. However, when accompanying Dr $\mathrm{E}$. Dias on Terceira we found a single individual in a ravine on the north-east side of Caldeira da Santa Barbara. Forestry Guards have also reported individuals in the Vale do Azinhal near Pico Alto (E. Dias, pers. comm.).

New observations were also made on two of the rare endemic giant herbs of the Azores. We found two new populations of the endemic Lac- tuca watsoniana on Pico Rachado (part of Caldeira da Santa Barbara), Terceira and on north-east O'Pico. Both populations are small but reproducing well, although the population on Pico is in a small wooded gully only about $15 \mathrm{~m}$ by $15 \mathrm{~m}$ and is completely surrounded by pasture. Other populations recorded by Sjögren (1973) are two on Pico, one on Terceira, and one on Faial, but the persistence of some of these populations is in doubt. On Sao Miguel the only site is at Lagoa do Canario (G. Le Grand, pers. comm.).

We found the other giant herb species, Melanoselinum decipiens, a Macaronesian endemic, in new sites on Caldeira da Santa Barbara while with Dr Dias. A single individual was found inside the Caldeira and a population of about 30 plants in a ravine on Pico Rachado. Sjögren (1973) recorded this species as being present only in the Caldeira da Faial.

\section{Requirements for conservation and further investigation}

The coastal flora, although not endangered, is vulnerable to further development, particularly with increasing tourism. On Pico the area to the east of Cais do Pico contains most of the endemic species, and if protected could also include the area of coastal scrub behind it. This would not protect Azorina vidalii, however, for which a different site would have to be selected. The coast of the islands has not been extensively explored and better sites may exist.

Lowland forest may be reconstructed most usefully in an area of the plantations of Terra Cha on Terceira and perhaps in the small area on Sao Miguel, where the native trees are still common and may form a semi-natural forest if exotic trees were removed. The only area of intact lowland forest, the Erica forest on Terceira, which has already suffered from recent partial clearance, requires urgent protection.

Le Grand (1980) has reported on the conservation needs of Pico. He identified three major areas that need protection. One of these, Caveiro, is reported to have been largely cleared (Le Grand, pers. comm.), but it is probably worthy of further attention; viewed from a distance, forest appears to remain on the western 
slopes of the area. The second area is Misterio da Prainha, which supports only very immature forest. Lastly, the mountain of O'Pico itself needs effective protection; the forests have very largely been removed, but the high-altitude moorland vegetation is intact and unique. Other areas were also recommended for protection, including the forests of Misterio da Santa Luzia, Cabeço do Teixa, and Misterio de Sao Joao, which have been largely cleared for pasture or plantation forestry, and the forests of Cabeço do Escavaldo and Bosque da Junqueira, which are less disturbed.

We largely agree with these recommendations, but we believe that greater emphasis should be placed on conserving areas of the best developed forest, even though it is fragmented. For this purpose, the protection of the remaining forests of Chao Verde, Cabeço da Lavandeira and the broad-leaved forest south of Corre Agua, together with the areas suggested above, would protect the range of forest types found at higher altitudes on Pico. As these areas are mostly adjacent to the larger areas suggested for protection by Le Grand, their inclusion should not be difficult.

On Terceira the forests of Caldeira da Santa Barbara and near Juncal require protection, being unique in the large areas of undisturbed forest still remaining. However, both are threatened; Cryptomeria was being planted on Caldeira da Santa Barbara when we were there, although we have since heard that it has stopped $(\mathrm{E}$. Dias, pers. comm.). The Juncal area in the past has been threatened by plans for a quarry and now a road is being built to the east, which will provide better access. The remaining forests of Pico da Vara on Sao Miguel similarly require complete protection. However, a botanical reserve of just 200 ha has been set up by the Forestry Service, which controls the area.

There have been attempts in the past to set up protected areas on O'Pico and in the Caldeira on Faial. However, all former common land on the islands, which includes the majority of sites discussed above, is controlled by the Forestry Ser- vice. There is a Protection Service set up by the Azorean local government, but it has no jurisdiction over the Forestry Service, which is responsible for much of the clearance for pasture as well as for forestry.

Much further research is required into the forests of the Azores. On Pico undisturbed forest may still remain on the very steep northern slopes of Lomba above Sao Roque. This may be the last resort of the endemic Prunus on Pico and is the last recorded site of yew Taxus baccata (Guppy, 1917), which is now believed to be extinct in the Azores, although the difficult terrain means it has hardly been visited. The tract of virgin forest below Juncal on Terceira, which has never been biologically investigated, will probably be the most important site and it should be studied before it is disturbed by man.

\section{Acknowledgments}

This project was carried out with the help of funding from St John's, Selwyn and Sidney Sussex Colleges, Cambridge. We would also like to thank Dr Q. C. B. Cronk of the Cambridge Botany School for his help and encouragement, and most of all, Gerald Le Grand and Dr E. Dias of the Universidade dos Açores for their great help and enthusiasm.

\section{References}

Godman, F. du Cane. 1870. Natural History of the Azores or the Western Islands. John van Voorst, London.

Guppy, H.B. 1917. Plants, Seeds and Currents in the West Indies and the Azores. Williams and Norgate, London.

Le Grand, G. 1980 . Schema d'Orientation pour la Creation de Reserves Naturelles sur les iles de Pico, Graciosa, Sao Jorge, et Faial (archipel des Açores): Instituto Universitario des Açores, Ponta Delgada.

Le Grand, G., Sjögren, E. and Furtado, D.S. 1982. Pico da Vara. Universidade dos Açores, Ponta Delgada.

Haggar, J.P. 1988. The physiognomy and status of cloud forests of Pico Island, the Azores. Biol. Conserv. 46, 7-22.

Sjögren, E. 1973. Recent changes in the vascular flora and vegetation of the Azores Islands. Mem. Soc. Brot., 22, 1 453.

Sjögren, E. 1984. Açores Flores. Diraccao Regional de Turismo, Horta Faial. Publ., Uppsala.

J. P. Haggar, St. John's College, Cambridge CB2 1TP, UK. A. R. Westgarth-Smith, Selwyn College, Cambridge CB3 9DQ, UK (current address: 4 Dawes East Road, Burnham, Slough SL1 8BT, UK).

D. Penman, Sidney Sussex, Cambridge CB2 3HU, UK. 